\title{
Gender Differences in Mathematics Ability of Junior High School Students based on Bloom's Taxonomy
}

\author{
Jeri Araiku $^{1^{*}}$, Rhodinus Sidabutar ${ }^{2}$, Jackson Pasini Mairing ${ }^{3}$ \\ ${ }^{1}$ Universitas Sriwijaya, Palembang, Sumatera Selatan 30139, Indonesia \\ ${ }^{2,3}$ Universitas Palangkaraya, palangkaraya, Kalimantan Tengah 73111, Indonesia \\ Pengiriman: 29 Januari 2019; Diterima: 23 April 2019; Publikasi: 30 April 2019 \\ DOI: https://doi.org/10.31629/jg.v4i1.969
}

\begin{abstract}
Abstrak
Tujuan dari penelitian ini adalah untuk menganalisis perbedaan kemampuan matematika dalam domain taksonomi bloom berdasarkan gender. Penelitian ini merupakan penelitian kuantitatif dengan 156 siswa sebagai sampel yang terdiri atas 81 laki-laki dan 75 perempuan. Uji anova dua jalur digunakan pada penelitian ini, dengan LSD (Least Significant Difference) dan HSD (Honestly Significant Difference) sebagai uji lanjutan. Hasil analisis menunjukkan bahwa seluruh uji prasyarat untuk analysis varians terpenuhi. Dari uji anava dua jalur, diperoleh hasil bahwa $F_{h i t u n g}$ $>\mathrm{F}_{\text {tabel }}$ pada $\alpha=0.05\left(\mathrm{~F}_{\text {hitung }}=10.57\right.$ dan $\left.\mathrm{F}_{\text {tabel }}=2.22\right)$ yang berarti terdapat interaksi antara gender dan level kognitif siswa. Uji LSD menunjukan bahwa pada level C1 (mengingat), siswa laki-laki lebih baik dibandingkan perempuan. Tetapi, tidak terdapat perbedaan performa siswa laki-laki dan perempuan secara keseluruhan. Uji HSD menunjukkan terdapat perbedaan signifikan pada performa siswa pada level C1 (mengingat), C2 (memahami), dan C3 (menerapkan), namun tidak di C4 (menganalisis), C5 (mengevaluasi), dan C6 (menciptakan). Oleh sebab itu, penting untuk merancang pembelajaran untuk meningkatkan kemampuan berpikir tingkat tinggi siswa.
\end{abstract}

Kata kunci: gender; taksonomi bloom; level kognitif; kemampuan matematika

\begin{abstract}
The purpose of this research is to analyze the difference of students' mathematics ability in bloom's taxonomy domain based on gender. This research is quantitative research with 156 students taken as sample, consisted of 81 male and 75 female students. Two-way anova employed in this study, with LSD (Least Significant Difference) and HSD (Honestly Significant Difference) as post hoc test. The results showed that all assumption tests for variance analysis wee fulfilled. From two-way anova test, obtained the result that $F_{\text {count }}>F_{\text {table }}$ at $\alpha=0.05\left(F_{\text {count }}=10.57\right.$ dan $\left.F_{\text {table }}=2.22\right)$ which meant that there was interaction between gender and students' cognitive level. LSD test showed that at level C1 (remember), male students performed better than female groups. However, there was no difference between both groups for overall performance. HSD test also revealed that there was significant difference on students' performance in C1 (remember), C2 (understand), and C3 (apply), but not in C4 (analyze), C5 (evaluate), and C6 (create). Therefore, it's important to design mathematics instruction to promote students higher order thinking.
\end{abstract}

Keywords: gender; bloom's taxonomy; cognitive level; mathematics ability 


\section{JURNAL GANTANG. April 2019; IV(1): 15 - 26 \\ p-ISSN. 2503-0671 \\ e-ISSN. 2548-5547}

\section{Preliminary}

Gender is a concept that raises many questions and is examined by many parties. In the world of research and education, the concept of gender is important to be explored. The reason for consistently considering gender in implementation research is multidimensional. Gender are important in policy-making to equality (Cuadrado, García-Ael, \& Molero, 2015), preferences for the uptake of interventions (Stanley, Ellis, Farrelly, Hollinghurst, \& Downe, 2015), also to add insight and enrich strategic intervention for instruction (Uluç, 2017). Furthermore, without proper study, implementation strategies may inadvertently exploit or ignore, rather than transform thinking about gender-related factors (Tannenbaum, Greaves, \& Graham, 2016).

According to Sasongko (2009), gender is the difference in roles, functions, and responsibilities between men and women which are the results of social construction and can change according to the times. The difference between women and men is essentially the result of socio-cultural construction resulting in different roles and tasks. This difference is seen as a nature as a result of biological differences (sex) which causes the way to treat men and women differently. Therefore, in order to survive, they must adapt to circumstances that make them more or less different in nature between men and women. This adaptation influenced their attitude, motivation, and even school performance.

On the other hand, gender and education are always interesting to be studied, due to no certainty in results regarding gender and school achievement (Hannover \& Kessels, 2011; Stanat, Pant, Böhme, \& Richter, 2012; Weis, Heikamp, \& Trommsdorff, 2013). For example, Spinath, Freudenthaler, \& Neubauer (2010) stated the importance of behavior and motivation based on gender differences in school achievement. They found that a higher level of social life has strong correlation with higher grades for girls but lower grades for boys. Pomerantz, Altermatt, \& Saxon
(2002) noted that girls' attitude tends to please adults to a higher degree than do boys, which leads to girls' higher school grades.

Gender is also associated with students' mathematical abilities very often (Lindberg, Hyde, Petersen, \& Linn, 2010; Mcphan, Morony, Pegg, Cooksey, \& Lynch, 2008; Strand, Deary, $\&$ Smith, 2006). Some mixed evidences suggest that there is a relationship between gender and one's mathematical abilities that could be explained in part by a higher variance of boys' in comparison to girls' school achievement (Machin \& Pekkarinen, 2008). The research revealed by Bailey, Watts, Littlefield, \& Geary (2014) suggests that at the elementary school level, female students have better mathematics achievements than male students. This is because in working on the questions, female students work more carefully, while for male students, they tend to solve the problems quickly because they are not afraid to be wrong (Bailey et al., 2014). Because they are not careful, they tend to have many incorrect answers and hence the learning outcomes are still under the female students.

But gradually, this pattern of thinking will actually have a reverse impact on learning outcomes when they enter $7^{\text {th }}$ grade and above. Male students will have better results than female students, because they are trained to be faster in thinking compared to female students, with a better level of accuracy than when they were in elementary school. This Bailey's statement is supported by the research results of Niederle \& Vesterlund (2010), stating that there are different responses from men and women in terms of competition. Their research resulted in the fact that men have a greater competitive nature than women. Furthermore, they also explained that there was an influence of competition on the results of mathematics tests.

On the other hand, several studies also mention that gender does not affect a person's mathematical abilities (Hannover \& Kessels, 2011). One of them is research conducted by 
Cerezo Rusillo \& Casanova Arias (2004), where gender does not affect the performance of students achieved in mathematics. Prior study by Hall \& Hoff (1988) also stated that there were no significant differences in students' mathematical performance based on gender differences.

Many research try to connect gender and mathematical ability based on motivation, selfregulation, behavior, and mathematics achievement (Cerezo Rusillo \& Casanova Arias, 2004; Cleary \& Chen, 2009; Lindberg et al., 2010). But the next questions that arise are, "do the differences in abilities found in male and female students occur at all levels of cognitive intelligence?" If their abilities are the same, "do they apply at all levels of cognitive intelligence?". To date, little to no studies have classified these differences into levels of cognitive intelligence. The conclusions in these studies are still general in nature, meaning that they have not been divided based on the level of one's cognitive intelligence.

In the learning process, assessment for the cognitive domain is the clearest to be measured. According to Anderson \& Krathwohl (2003), based on Bloom's Taxonomy, a person's cognitive intelligence is divided into 6 levels, namely: (1) Remember (C1); (2) Understand (C2); (3) Apply (C3); (4) Analyze (C4); (5) Evaluate (C5), and; (6) Create (C6). For the cognitive domain, it can be assessed using practice questions. With the different levels of ability in the cognitive domain, the questions faced by students can also be modified to have different levels of difficulty according to the levels from $\mathrm{C} 1$ to $\mathrm{C} 6$. Based on the theories disclosed by (Anderson \& Krathwohl, 2003), (Fisher, 2005), (Alfeld, 2012), (Krulik, S., Rudnick, J., \& Milou, 2003), the criteria of cognitive ability can be seen on Table 1 .

Table 1 .

Matrix of cognitive ability criteria

\begin{tabular}{ll}
$\begin{array}{l}\text { Bloom's } \\
\text { Taxonomy }\end{array}$ & \multicolumn{2}{c}{ Cognitive Ability Criteria } \\
\hline C1 & 1. $\begin{array}{l}\text { Recalling mathematics formula, } \\
\text { definition, or theorem. }\end{array}$
\end{tabular}

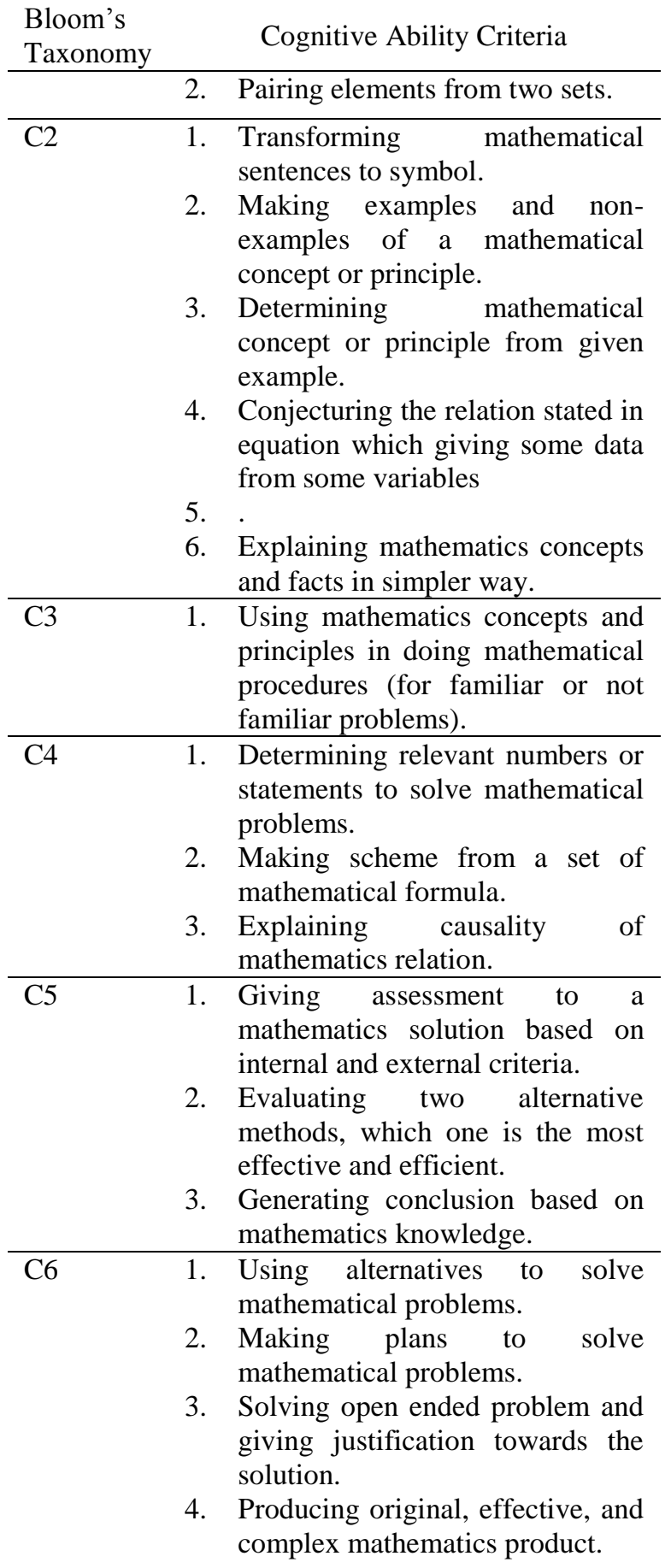

*Essenced from (Anderson \& Krathwohl, 2003), (Fisher, 2005), (Alfeld, 2012), (Krulik, S., Rudnick, J., \& Milou, 2003).

Therefore, based on the importance and contribution described above, the purpose of this research is to discover the difference of mathematical cognitive ability based on gender from the perpective of Bloom's taxonomy. 


\section{JURNAL GANTANG. April 2019; IV(1): 15 - 26 \\ p-ISSN. 2503-0671 \\ e-ISSN. 2548-5547}

\section{Research Method}

This

study is

quantitative

research. In this study, researchers conducted a cross-sectional survey, by giving tests without artificial treatment to the research subject. The instrument was a test consisted of 6 questions, where each question represents Bloom's level of cognitive as shown in Figure 1. The materials tested in this research were geometry and set.

1. What is the formula for area of a rectangle if the length $(p)$ and width $(I)$ ?

2. Name each triangle based on its angles!

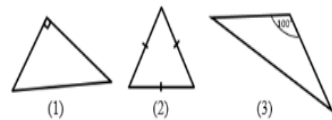

3. Determine the total area of the following figure!

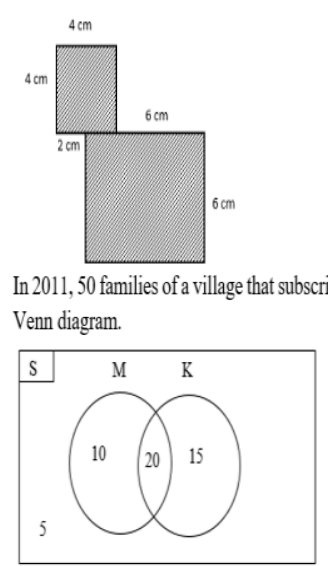

In 2012, 5 families that initially didn't subscribe newspaper nor magazine, choose to subscribe newspaper, and 10 families that initially subscribed newspaper only, choose to subscribe magazine as well, and 4 families that subscribed magazine and newspaper, stop subscribing. Determine:

a. Total family that subscribe newspaper in 2012 .

b. Total family that subscribe magazine only in 2012 .

c. Total family that subscribe both newspaper and magazine in 2012 .

d. The Venn diagram.

5. One day, Andi showed Budi a picture of following rectangle.

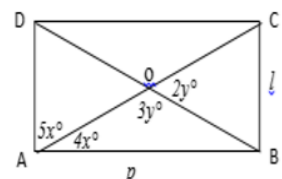

If Andi asked Budi to draw the rectangle with its real measures, is there any value that satisfies $x$ and $y$ so that the picture form a rectangle shape? Explain!

6. In a class of 30 students, 15 students like to read and 15 students like to draw.

a. How many students like to both read and draw?

b. Is there any other possible answer? Explain!

Figure 1. Test item

The research design in this study is factorial design. The results obtained will be classified according to the problem categories based on Bloom's Taxonomy. The design of classification of the results is shown in Table 2.
Table 2.

Design of research results

Learning Achievement

\begin{tabular}{lcccccc} 
Gender & \multicolumn{1}{c}{$C 1$} & $C 2$ & $C 3$ & $C 4$ & $C 5$ & $C 6$ \\
\hline Male & $Y M C 1$ & $Y M C 2$ & $Y M C 3$ & $Y M C 4$ & $Y M C 5$ & $Y M C 6$ \\
\hline Female & $Y F C 1$ & $Y F C 2$ & $Y F C 3$ & $Y F C 4$ & $Y F C 5$ & $Y F C 6$
\end{tabular}

Where:

$Y i C j=$ Test result of gender $i$ at cognitive level $j$.

$i=$ Male $(M)$, Female $(F)$

$j=1,2,3,4,5,6$

Population in this study were $2638^{\text {th }}$ grade students of one junior high school in Palangkaraya, consisting of 137 males and 126 females. The sampling technique in this study is cluster random sampling, by determining the number of samples using a formula developed by (Isaac \& Michael, 1995). From 263 subject, with significance level of 5\% (0.05), and degrees of freedom $(d f)=1$, obtained total sample of 156 students. Subsequently determining sample size is based on the gender ratio, therefore the samples used were 81 male students and 75 female students.

The hypothesis in this study is whether there are differences in mathematics learning achievement between male and female students at each cognitive intelligence level $\mathrm{C} 1$ to C6. The hypothesis test used is a Two-way anova. The test employed for two main reasons: (1) the analysis consisted of two independent variables (gender and bloom's taxonomy, and (2) the analysis should be done at once (to preserve the 5\% alpha). Before conducting a Two-way anova test, we will perform assumption tests underlying the analysis of variance (Gaspersz, 1994), namely: linearity, normality, homogeneity, and randomness of errors. The linearity test is done by determining the general linear model for the factorial design factorial. The normality test performed is to use visuals from the normal curve by making a histogram of the residual data of the students' test results. To test the homogeneity, a plot is 
made between the standard residuals and the estimated value of fit (Groeneveld, 1988). Randomness of errors testing is by creating a residual histogram versus order. The requirement for randomization of the error is said to be fulfilled if the points on the histogram spread randomly around 0 .

If the two-way anova test shows that the interaction effect is different, then the researcher will conduct post hoc tests to find out the different components of the results of the study, namely the LSD (Least Significant Difference) test and the HSD (Honestly Significant Difference) test. The LSD test aims to determine the differences in mathematical abilities between male and female students at certain cognitive levels. While the purpose of the HSD test is to determine whether or not the influence of Bloom's Taxonomy or real differences has occurred.

\section{Result and Discussion Descriptive Result}

The average score of male and female student groups can be seen in Figure 2.

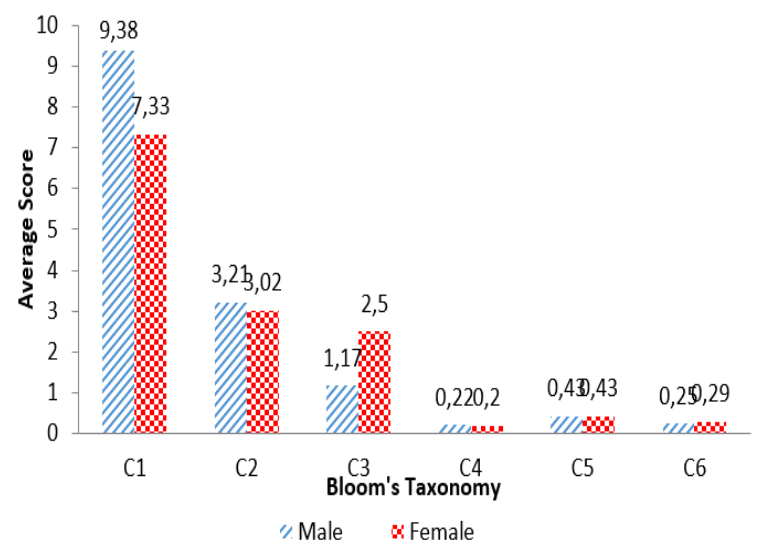

Figure 2. Average score of male and female students

Based on the bar diagram above, it can be seen that:

1. At the cognitive level $\mathrm{C} 1$, the average score of male is higher than that of female students. The average value of male is 2.05 or $27.97 \%$ higher. Researchers suspect that male have better mathematical abilities in level $\mathrm{C}$.
Example of student's answer is showed in Figure 3.

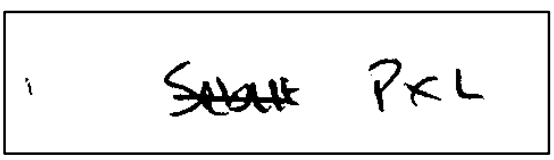

Figure 3. Student's answer for C1

2. At the cognitive level of $\mathrm{C} 2$, the average value of male is higher than that of female, but this difference is very small, which is only 0.19 or $6.29 \%$. So, it can be said that at level $\mathrm{C} 2$ there is no significant difference. The researchers suspected that there were no differences in mathematical abilities in male and female in the $\mathrm{C} 2$ category.

3. At the C3 cognitive level, there is a significant difference that is equal to 1.33 or $113.68 \%$. But at this cognitive level, higher mean values are actually female students. With a difference of $113.68 \%$, it can be said that female students are twice as good as male. Researchers suspect that female have better mathematical abilities in the $\mathrm{C} 3$ category.

4. At the cognitive level $\mathrm{C} 4, \mathrm{C} 5$, and $\mathrm{C} 6$, there is no significant difference, because all the differences are below the 0.05 level. Even for the $\mathrm{C} 5$, there is no difference at all. All students couldn't solve the problem properly, since the problem required not only procedural computation, but also analysis and evaluation. For example in C5, students stated that there's value of $x$ and $y$ so that the plane could form a rectangle. However, if we put any $x$ and $y$ of student's answer, it will not forming the shape of rectangle, since there's no value of $x$ and $y$ that satisfied the condition. Both groups of subjects got a mean of 0.43 . Researchers suspect that there is no difference in mathematical abilities between male and female in the $\mathrm{C} 4, \mathrm{C} 5$ and $\mathrm{C} 6$ categories. Example of student's answer for item C5 is showed in Figure 4. 
JURNAL GANTANG. April 2019; IV(1): 15 - 26

p-ISSN. 2503-0671

e-ISSN. 2548-5547

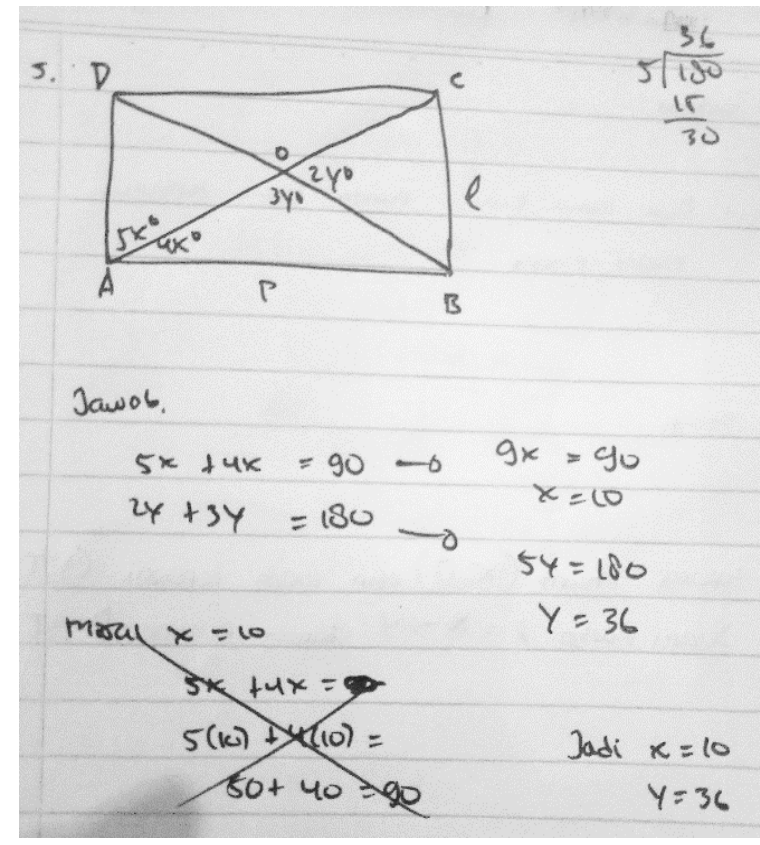

Figure 4. Student's answer for C5

The comparison of the score from each group against the total average, can be seen in Table 3.

Table 3.

Average value

\begin{tabular}{llllllll} 
& $\mathrm{C} 1$ & $\mathrm{C} 2$ & $\mathrm{C} 3$ & $\mathrm{C} 4$ & $\mathrm{C} 5$ & $\mathrm{C} 6$ & Avg \\
\hline $\mathrm{M}$ & 9.38 & 3.21 & 1.17 & 0.22 & 0.43 & 0.25 & 2.44 \\
\hline $\mathrm{F}$ & 7.33 & 3.02 & 2.5 & 0.2 & 0.43 & 0.29 & 2.3 \\
\hline Avg & 8.36 & 3.12 & 1.84 & 0.21 & 0.43 & 0.27 &
\end{tabular}

From Table 3, it can be seen that:

1. For male students, when compared to the average value, only $\mathrm{C} 1$ and $\mathrm{C} 2$ values exceed the average value, while for $\mathrm{C} 3, \mathrm{C} 4, \mathrm{C} 5$, and C6 it is below the value of 2.44 .

2. For female students, when compared to the average value, the values $\mathrm{C} 1, \mathrm{C} 2$, and $\mathrm{C} 3$ exceed the average value, while for $\mathrm{C} 4, \mathrm{C} 5$, and $\mathrm{C} 6$ are below the value of 2.3.

3. The average value of male students is higher compared to female students. Thus, it can be concluded that overall, the value of male students is better than female students.

\section{Assumption Tests}

The assumptions that need to be fulfilled before perform the two-way Anova test are 4, namely as follows:

1. Linearity
The general linear model of this study is:

$$
\begin{aligned}
Y_{j}= & M C_{1} \beta_{1}+M C_{2} \beta_{2}+M C_{3} \beta_{3}+M C_{4} \beta_{4}+ \\
& M C_{5} \beta_{5}+M C_{6} \beta_{6}+F C_{1} \beta_{7}+F C_{2} \beta_{8}+ \\
& F C_{3} \beta_{9}+F C_{4} \beta_{10}+F C_{5} \beta_{11}+F C_{6} \beta_{12}+\varepsilon_{j}
\end{aligned}
$$

Where:

$Y_{j}=$ response variable in linear combination.

$\beta_{l}=$ parameter (coefficient) for each explanation variable $x_{j l}$.

$\varepsilon_{j}=$ residual value for each $Y_{\mathrm{j}}$.

$M C_{i}=$ Male for taxonomy level of bloom i.

$F C_{i}=$ Female for taxonomy level of bloom $\mathrm{i}$.

Linearity is fulfilled if the effect of treatment is additive. Additive means that it can be summed according to a particular model (Gaspersz, 1994). Because the research model is additive, the assumption of linearity is fulfilled.

2. Normality test

Normality is seen in Figure 5 of the normal curve by using histograms of residual data from the research results with calculations using the help of the Minitab16.2.

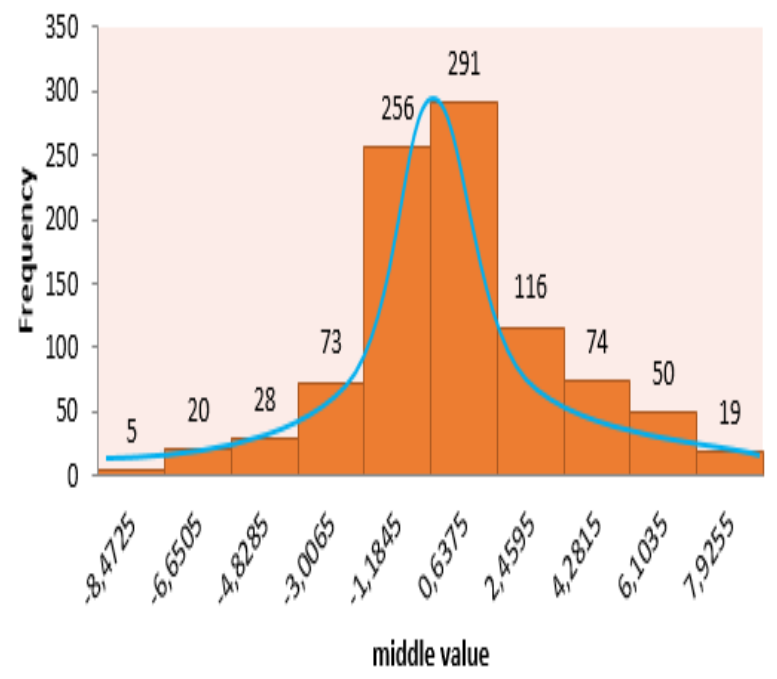

Figure 5. Residual histogram test results

In Figure 4, the distribution value of residual data tends to be normal, even though the normal curve looks sharp.

\section{Homogeneity Test}

In Figure 6, it can be seen that the points are spread on both the positive and negative sides of the residual. Therefore the residual data meets the requirements of homogeneity test. 


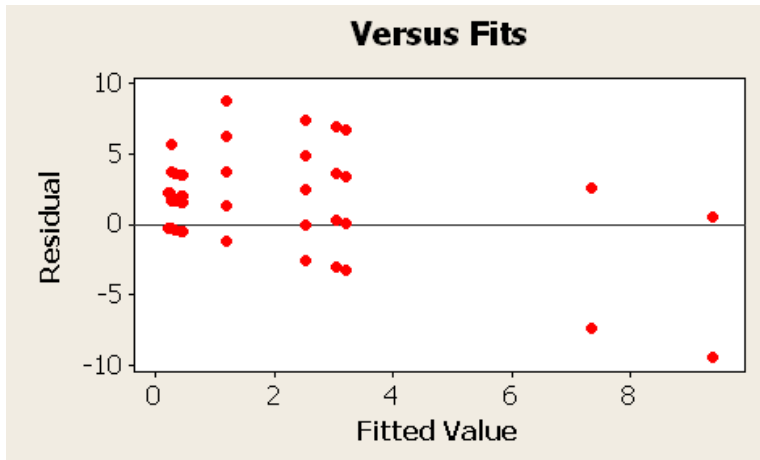

Figure 6. Residual versus fit histogram

4. Randomness of errors

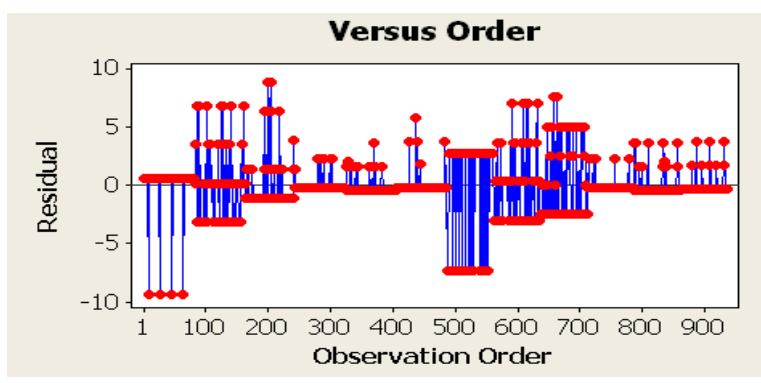

Figure 7. Residual versus Order Histogram

In Figure 7, it can be seen that the points are scattered randomly around 0 . Thus, the residual data meets the randomization requirements of the error.

Based on the assumption tests, researchers tend to use the two-way anova test to determine the differences in cognitive ability of male and female students due to the following reasons:

1. Assumptions for two-way anova testing tend to be fulfilled.

2. There are no non-parametric statistics that correspond to the two-way anova with a factorial design.

3. If the researcher compares each combination of research components one by one (for example by the student t-hypothesis test), with each test using a significant level of $5 \%$, then with 6 tests, the researcher will make a mistake of $1-(0.95)^{6}=26.49 \%$. (Gaspersz, 1994).

\section{Two-way Anova Test}

From the data obtained, it can be seen that the average score of male students $\left(\bar{X}_{l}=2.44\right)$ showed better results compared to female student test scores $\left(\bar{X}_{p}=2.295\right)$.
However, the result is not convincing if not analyzed further. To test the statistical analysis hypothesis, a two-way analysis of variance was used.

Based on the results of the two-way anova test, the results are as follows.

Table 4.

Summary of two-way anova test

\begin{tabular}{llllll}
$\begin{array}{l}\text { Variance } \\
\text { Source }\end{array}$ & df & $\begin{array}{l}\text { Total } \\
\text { Square }\end{array}$ & $\begin{array}{l}\text { Mean } \\
\text { Square }\end{array}$ & $\begin{array}{l}\text { F } \\
\text { count }\end{array}$ & $\begin{array}{l}\mathrm{F} \\
\text { table }\end{array}$ \\
\hline $\begin{array}{l}\text { Bloom's } \\
\text { Taxonomy }\end{array}$ & 5 & 7808.55 & 1561.71 & 286.02 & 2.22 \\
\hline Gender & 1 & 4.93 & 4.93 & 0.9 & 3.85 \\
\hline $\begin{array}{l}\text { Interaction } \\
\text { bloom } \times \\
\text { gender) }\end{array}$ & 5 & 288.65 & 57.73 & 10.57 & 2.22 \\
\hline Error & 924 & 5048.07 & 5.46 & & \\
\hline Total & 935 & 13090.2 & & &
\end{tabular}

For interactions between Bloom's Taxonomy and gender, based on $\mathrm{df}$ (5:924), then $\mathrm{F}_{\text {table }}=2.22$ for $\alpha=5 \%$. The value of $\mathrm{F}_{\text {count }}=$ $10.57>F_{\text {table. }}$. Because the value of $F_{\text {count }}$ is more than the value of $F_{\text {table }}$, then $\mathrm{H}_{\mathrm{o}}$ is rejected and $\mathrm{H}_{\mathrm{a}}$ is accepted. This means that there is an interaction between certain levels of cognitive intelligence based on Bloom's Taxonomy and gender differences in student mathematics achievement.

Because of the real influence of the interaction, the researcher will conduct a post hoc test, namely the LSD test, to see the mathematics ability difference of male and female students at a certain cognitive level, and HSD test to see differences in each category in bloom's taxonomy.

\section{LSD Test}

Based on the calculation, the LSD value of 1.5627 is obtained. Because the value $\left|\bar{Y}_{L}-\bar{Y}_{P}\right|=0,87<L S D_{0,05}=1,5627$, thus, it was concluded, the overall ability of male and female students is not significantly different. The overall ability is not significantly different, meaning that the mean scores of the total scores obtained by the male and female student groups do not differ. But in the two-way anova test, the 


\section{JURNAL GANTANG. April 2019; IV(1): 15 - 26 \\ p-ISSN. 2503-0671 \\ e-ISSN. 2548-5547}

interaction between gender and bloom's taxonomy was significantly different. This means that there are at least one pair of $\mathrm{LC}_{\mathrm{i}}$ and $\mathrm{PC}_{\mathrm{i}}$ that is differ. After investigate the result deeper, the results are as follows:

1. $\left|\bar{Y}_{L C 1}-\bar{Y}_{P C 1}\right|=2,05>L S D_{0,05}=1,5627$, then the ability of male and female students at $\mathrm{C} 1$ is significantly different.

2. $\left|\bar{Y}_{L C 2}-\bar{Y}_{P C 2}\right|=0.19<L S D_{0,05}=1,5627$, then the ability of male and female students at $\mathrm{C} 2$ is not significantly different.

3. $\left|\bar{Y}_{L C 3}-\bar{Y}_{P C 3}\right|=1,33<L S D_{0,05}=1,5627$, then the ability of male and female students at $\mathrm{C} 3$ is not significantly different.

4. $\left|\bar{Y}_{L C 4}-\bar{Y}_{P C 4}\right|=0,02<L S D_{0,05}=1,5627$, then the ability of male and female students at $\mathrm{C} 4$ is not significantly different.

5. $\left|\bar{Y}_{L C 5}-\bar{Y}_{P C 5}\right|=0<L S D_{0,05}=1,5627$, then the ability of male and female students at C5 is not significantly different.

6. $\left|\bar{Y}_{L C 6}-\bar{Y}_{P C 6}\right|=0,04<L S D_{0,05}=1,5627$, then the ability of male and female students at C6 is not significantly different.

\section{HSD Test}

Based on calculations, the results of the HSD value is 0.231 . The difference value of the average absolute value for each level of bloom's taxonomy can be seen as follows.

Table 5.

Different of average absolute value

\begin{tabular}{ccccccc} 
& C4 & C6 & C5 & C3 & C2 & C1 \\
\hline Avg & 0.21 & 0.27 & 0.43 & 1.835 & 3.115 & 8,335 \\
\hline Diff & 0.08 & 0.16 & 1.405 & 1.28 & 5.22
\end{tabular}

The HSD value is compared with the absolute difference between the two average values with the criteria:

1. For the two averages are said to be no different, if the absolute difference is less than or equal to HSD.

2. For the two treatment averages are said to be different, namely if the absolute difference is more than HSD.

Thus, it can be concluded as follows:
1. The level of knowledge of students in $\mathrm{C} 4$, C5, and C6 there is no difference.

2. The level of students 'knowledge on $\mathrm{C} 4, \mathrm{C} 5$, and $\mathrm{C} 6$, is different from the level of students' knowledge on C3.

3. The level of students 'knowledge on C3 is different from the level of students' knowledge on $\mathrm{C} 2$. In other words, the level of knowledge of students $\mathrm{C} 4, \mathrm{C} 5$, and $\mathrm{C} 6$, is also different from students' knowledge on $\mathrm{C} 2$.

The level of student knowledge at $\mathrm{C} 2$ is different from the level of knowledge of students in C1. In other words, the level of knowledge of students $\mathrm{C} 4, \mathrm{C} 5$, and $\mathrm{C} 6$, is also different from the knowledge of students in $\mathrm{C} 1$, and the level of students' knowledge on $\mathrm{C} 3$ is also different from the level of knowledge $\mathrm{C} 1$ in students.

\section{Disscussion}

From Figure 2, we can see that students' average score are consistently decreasing as the cognitive level higher. It means higher cognitive level means harder and more complex problem the students have to solve. If we separate the results, $\mathrm{C} 1$ to $\mathrm{C} 3$ level (lower order thinking skills) are practically higher than $\mathrm{C} 4$ to $\mathrm{C} 6$ (higher order thinking skills). There several reasons that potentially cause this phenomenon.

1. The nature of cognitive level is overlapping (see Figure 8). In order to master $\mathrm{C} 1$, we don't need to master $\mathrm{C} 2$ to $\mathrm{C} 6$, or in order to have good computation skill (C3), one doesn't necessary need to master $\mathrm{C} 4$ to $\mathrm{C} 6$. On the other hand, in order to master $\mathrm{C} 2$, mastering $\mathrm{C} 1$ is a must. Or in order to possess creative thinking skill, all $\mathrm{C} 1$ and $\mathrm{C} 5$ must be mastered.

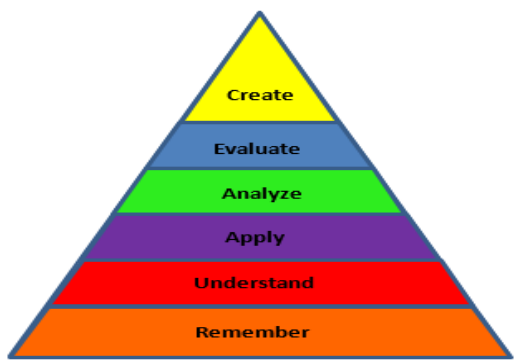

Figure 8. Thinking pyramid 
2. The instructions don't take higher order thinking skill (HOTs) learning process into count. Teachers are not considering the importance of HOTs in learning process (Bahar, 2011). It's general sense that education is transferring knowledge from all learning resources to students. This process can take many forms, i.e. demonstration, direct learning, instructional media, and practices (Walle, J., Karp, K., \& Williams, 2010). Teacher needs to put students to solve mathematical problem (Susanti et al., 2016), since the learning process mostly depends on the teacher, i.e. to design the instruction as effective as possible to let the students develop their HOTs, from determining the learning objectives, employing various teaching method (like inquiry and problem based learning), through designing HOTs practices (Limbach \& Waugh, 2010). This is important to maximize the potential of HOTs which students basically already have.

3. Students' attitude towards solving higher level problems isn't good. Some research suggests that there is strong connection between students' belief, anxiety, and selfregulation towards mathematics learning achievements (Ahmad Tarmizi \& Suthar, 2010; Cleary \& Chen, 2009).

4. Transition from Lower order thinking skill (LOTs) to higher order thinking skill (HOTs) are not fully develop. In order to solve HOTs, it takes more comprehensive understanding towards mathematical concepts, including algebraic thinking ability. Since C4 to C6 problems handed to students demand algebraic thinking ability, most students made mistakes in solving the problems. This result in line with result from (Pratiwi \& Kurniadi (2018), where students still made errors while performing negative number operations even when the transition indicator of the ability of arithmetic thinking to the ability of algebraic thinking achieved well.

In this study it was also known that in the cognitive domain of $\mathrm{C} 1$, male were better than female students. The $\mathrm{C} 1$ question is quite easy, most students could answer correctly. However, while majority of male students answered that item correctly, around a quarter of total female student left blank answer to the question (see Figure 2).

One of the potential reason is on how male and female brain works. This is supported by the fact revealed by (Gurian, 2002), that the male and female brains are basically different. Boys' brains are better suited to recognize symbols, forms of abstraction, diagrams, images and moving objects than monotonous words. For this reason, Gurian concluded that male are superior in mathematics and physics, especially when the subject is taught abstractly in front of the class.

However, even when there is significant different in $\mathrm{C} 1$, there is no significant different of overall score between male and female group. Since the difference is only found in the cognitive domain of $\mathrm{C} 1$, so the contribution that causes a difference is in a small total value.

\section{Conclusion}

From the result, it shows that there is interaction between gender and bloom's taxonomy. After LSD test, there are no significant difference at cognitive level C2 (understand), C3 (apply), C4 (analysis), C5 (evaluate), and C6 (create), while there is significant difference at level $\mathrm{C} 1$ (remember), where male performed better than female students. However, overall performance doesn't show any significant different. It's because that the difference only happen in $\mathrm{C} 1$, therefore is it's compared with total score, the contribution of $\mathrm{C} 1$ is relatively small. One factor that may cause this is because male and female brain works differently (Gurian, 2002). Boys' brains are better suited to recognize symbols, forms of abstraction, diagrams, images and moving objects than monotonous words. For this reason male are superior in mathematics and physics, especially when the subject is taught abstractly in front of the class.

Furthermore, students' performance is 


\section{JURNAL GANTANG. April 2019; IV(1): 15 - 26 \\ p-ISSN. 2503-0671 \\ e-ISSN. 2548-5547}

decreasing as the level of problem increasing. Based on HSD test, there is significant different in cognitive level $\mathrm{C} 1, \mathrm{C} 2$, and $\mathrm{C} 3$, while no significant difference in $\mathrm{C} 4, \mathrm{C} 5$, and C6. Many causes could be the factors, like the nature of cognitive level is overlapping, instructional process doesn't consider HOTs to be implemented, students' attitude towards mathematics, and transition from arithmetic to algebraic thinking is underdeveloped. However, these assumptions need to be taken further research. The most important thing for mathematics practitioners, especially teachers, to start consider to design mathematics instruction and employ all media necessary in order to help students develop their HOTs.

\section{References}

Ahmad T. R., \& Suthar, V. (2010). Effects of students' beliefs on mathematics and achievement of university students: Regression analysis approach. Journal of Social Sciences, 6(2), 146-152. https://doi.org/10.3844/jssp.2010.146.152

Alfeld, P. (2012). Understanding mathematics. retrieved from http://www.math.utah.edu/ alfeld/math.htm 1

Anderson \& Krathwohl. (2003). A Taxonomy for learning, teaching, and assessing: $A$ revision of bloom's taxonomy of educational objectives. New York: David McKay Company, Inc.

Bahar, K. (2011). Exploring the relationship between mathematical creativity and mathematical achievement. Asia-Pacific Journal of Gifted and Talented Education, 3(1), 33-48.

Bailey, D. H., Watts, T. W., Littlefield, A. K., \& Geary, D. C. (2014). State and trait effects on individual differences in children's mathematical development. Psychological Science, 25(11), 2017-2026. https://doi.org/10.1177/0956797614547539

Cerezo R. M. T., \& Casanova A. P. F. (2004). Gender differences in academic motivation of secondary school students. Electronic
Journal of Research in Educational Psychology, 2(1), 97-112. Retrieved from http://www.investigacion-

psicopedagogica.org/revista/articulos/3/eng lish/Art_3_31

Cleary, T. J., \& Chen, P. P. (2009). Selfregulation, motivation, and math achievement in middle school: Variations across grade level and math context. Journal of School Psychology, 47(5), 291314.

https://doi.org/10.1016/J.JSP.2009.04.002

Cuadrado, I., García-Ael, C., \& Molero, F. (2015). Gender-typing of leadership: Evaluations of real and ideal managers. Scandinavian Journal of Psychology, $56(2)$, 236-244. https://doi.org/10.1111/sjop.12187

Fisher, D. (2005). Emerging perspectives on learning, teaching, and technology. Georgia: Oregon State University.

Gaspersz. (1994). Metode perancangan percobaan. Bandung: Armico.

Groeneveld. (1988). Introductory statistical methods: An integrated approach using minitab. Boston: PSW-KENT Publishing Company.

Gurian. (2002). Boys and girls learn differently!: A guide for teachers and parents. San Francisco: Jossey-Bass.

Hall, C. W., \& Hoff, C. (1988). Gender differences in mathematical performance. Educational Studies in Mathematics, 19(3), 395-401. https://doi.org/10.1007/BF00312455

Hannover, B., \& Kessels, U. (2011). Sind jungen die neuen bildungsverlierer? empirische evidenz für geschlechterdisparitäten zuungunsten von jungen und erklärungsansätze 1dieser beitrag wurde unter der geschäftsführenden herausgeberschaft von jens möller angenommen. . Zeitschrift Für Pädagogische Psychologie, 25(2), 89-103. https://doi.org/10.1024/1010-0652/a000039 Isaac, S., \& Michael, W. B. (1995). Handbook in 
research and evaluation: A collection of principles, methods, and strategies useful in the planning, design, and evaluation of studies in education and the behavioral sciences, $3 r d$ ed. Handbook in research and evaluation: A collection of principles, methods, and strategies useful in the planning, design, and evaluation of studies in education and the behavioral sciences, 3rd ed. San Diego, CA, US: EdITS Publishers.

Krulik, S., Rudnick, J., \& Milou, E. (2003). Teaching mathematics in middle schools: a practical guide. Boston: Pearson Education Inc.

Limbach, B., \& Waugh, W. (2010). Developing higher level thinking. Journal of instructional pedagogies. Retrieved from https://aabri.com/manuscripts/09423.pdf

Lindberg, S. M., Hyde, J. S., Petersen, J. L., \& Linn, M. C. (2010). New trends in gender and mathematics performance: a metaanalysis. Psychological Bulletin, 136(6), 1123-1135.

https://doi.org/10.1037/a0021276

Machin, S., \& Pekkarinen, T. (2008). Global sex differences in test score variability. science, 322(5906), 1331-1332. https://doi.org/10.1126/science.1162573

Mcphan, G., Morony, W., Pegg, J., Cooksey, R., \& Lynch, T. (2008). Maths? Why Not? Final Report prepared for the Department of Education and Workplace Relations (DEEWR). Canberra: Department of Education, Employment and Workplace Relations.

Niederle, M., \& Vesterlund, L. (2010). Explaining the Gender gap in math test scores: the role of competition. Journal of Economic Perspectives, 24(2), 129-144. https://doi.org/10.1257/jep.24.2.129

Pomerantz, E. M., Altermatt, E. R., \& Saxon, J. L. (2002). Making the grade but feeling distressed: Gender differences in academic performance and internal distress. Journal of Educational Psychology, 94(2), 396-
404. https://doi.org/10.1037/00220663.94.2.396

Pratiwi, W. D., \& Kurniadi, E. (2018). Transisi kemampuan berpikir aritmatika ke kemampuan berpikir aljabar pada pembelajaran matematika. Jurnal Gantang, $3(1)$, $1-8$.

https://doi.org/10.31629/jg.v3i1.388

Sasongko. (2009). Konsep dan Teori Gender. Jakarta: Badan Koordinasi Keluarga Berencana Nasional.

Spinath, B., Freudenthaler, H., \& Neubauer, A. (2010). Domain-specific school achievement in boys and girls as predicted by intelligence, personality and motivation. Personality and Individual Differences, 48, 481-486.

https://doi.org/10.1016/j.paid.2009.11.028

Stanat, P., Pant, H. A., Böhme, K., \& Richter, D. (2012). Kompetenzen von schülerinnen und schülern am ende der vierten jahrgangsstufe in den fächern deutsch und mathematik. ergebnisse des igbländervergleichs. Zusammenfassung. Berlin: Waxmann.

Stanley, N., Ellis, J., Farrelly, N., Hollinghurst, S., \& Downe, S. (2015). Preventing domestic abuse for children and young people: A review of school-based interventions. Children and Youth Services Review. Stanley, Nicky: School of Social Work, University of Central Lancashire, Preston, United Kingdom, PR1 2HE, NStanley@uclan.ac.uk: Elsevier Science. https://doi.org/10.1016/j.childyouth.2015.1 0.018

Strand, S., Deary, I. J., \& Smith, P. (2006). Sex differences in cognitive abilities test scores: A UK national picture. British Journal of Educational Psychology, 76(3), 463-480. https://doi.org/10.1348/000709905X50906

Susanti, W., Nofrianto, A., Amri, M. A., Tinggi, S., Dan, K., \& Pendidikan, I. (2016). Matematika siswa melalui model pembelajaran laps- heuristic dikelas $\mathrm{X}$ SMAN 2. Jurnal Gantang, 1(2), 39-50. 
JURNAL GANTANG. April 2019; IV(1): 15 - 26

p-ISSN. 2503-0671

e-ISSN. 2548-5547

Tannenbaum, C., Greaves, L., \& Graham, I. D. (2016). Why sex and gender matter in implementation research. BMC Medical Research Methodology, 16(1), 1-9. https://doi.org/10.1186/s12874-016-0247-7

Uluç, F. Ö. (2017). How to approach teaching gender equality to boys and girls. Retrieved from https://www.britishcouncil.org/voicesmagazine/how-approach-teaching-genderequality-boys-and-girls

Walle, J., Karp, K., \& Williams, J. (2010). Elementary and middle school mathematics: Teaching developmentally seventh edition. Boston: Pearson Education, Inc.

Weis, M., Heikamp, T., \& Trommsdorff, G. (2013). Gender differences in school achievement: The role of self-regulation. Frontiers in Psychology, 4, 1-10. https://doi.org/10.3389/fpsyg.2013.00442 